\title{
LIDAR AND GIS TECHNIQUES IN THE SURVEY AND MONITORING OF BUILT HERITAGE: APPLICATION TO THE MAIN FRONTAGE OF THE CHURCH OF BIAR
}

\author{
JOSÉ ANTONIO HUESCA TORTOSA, DAVID TORREGROSA FUENTES, \\ MIGUEL LOUIS CERECEDA \& YOLANDA SPAIRANI BERRIO \\ Departamento de Construcciones Arquitectónicas, Universidad de Alicante, Spain
}

\begin{abstract}
In Biar, a town located within the province of Alicante, is located the Church of Nuestra Señora de la Asunción, declared as an Asset of Cultural Interest (BIC) since 1982. The church began to be built in the 15th century and still preserves today the most important Proto-Renaissance-style main frontage of the Valencian community. The construction of this façade is documented from 1529 by masters of carving and painting and it presents a great architectural and sculptural value for its time. Unfortunately, due to the location and orientation of the building, characteristics of the materials used, subsequent interventions and exposition to the environmental effects, the church presents a worrying conservation state which makes at least a preliminary diagnostic study necessary as a basis for eventual interventions. The diagnostic study presented in this paper uses non-destructive techniques based on the 3D-digitalization by scanning and obtaining the building point cloud for checking and monitoring deformations and movements of the targeted building and, particularly all integrating elements. Furthermore, this technique helps us to appreciate through successive scanning in time, the possible degradation of the stone material and material losses undergone by the elements under study, and together with the use of other software for the treatment and the comparison of point clouds (LIDAR) and geographic information systems (GIS), the ability to catalogue and analyse the evolution of this kind of damage, in addition to their application as useful tools in architectural archaeology. The results obtained have allowed the identification of zones with a higher degradation rate requiring urgent intervention, in addition to quantify the loss of material suffered in this period.
\end{abstract}

Keywords: Biar, Church of Biar, church façade of Biar, diagnostic study, point cloud, LIDAR, SIG, GIS.

\section{INTRODUCTION}

The façade of the Church of Our Lady of the Assumption located in the city of Biar, Alicante, former border town and royal villa since 1287, is one of the architectural jewels of the Valencian Community. It represents the typical Valencian Renaissance at the beginning of the XVI century, between the late Gothic and the first reminiscences of the Italian Renaissance, and is the first Renaissance main front in the province of Alicante.

Regarding the decorative elements, a juxtaposition of the new and the traditional is seen. On the one hand, laurels, putti, "grutescos", candelieri, "veneras", denticles, acanthus, "cameos", warheads, buccaneers, classic capitals with heads of rams, eagles and children coiled to the "caulículos". Along with medieval iconography based on high reliefs of various religious themes such as the representation of the Assumption of the Virgin among musicians, angels and kneeling apostles in the tympanum, and the Adoration of the Shepherds and the Magi, Virgin and Angel of The Annunciation, San Pedro and San Pablo, San Juan Bautista and San Sebastián, San Cristóbal and San Antonio Abad in the lateral niches.

All this decoration and staging on the stone needs a carving very well worked in addition to the choice of material according to the complexity of execution. It is for this reason that the material used is more "soft" than the material of the rest of the facade of the building, and 
for this reason an important factor that has contributed in the durability of the same and its state of erosion and deterioration in which it is nowadays.

Through the latest techniques of data collection with terrestrial laser scanner and methods of comparative analysis of points cloud obtained at different times, in addition to the use of geographic information processing systems applied to this area of diagnosis, the rate of deterioration and erosion undergone by these stone elements can be quantified.

\section{STATE OF THE-ART}

The non-destructive techniques that can be used for the diagnostic study of the built heritage give us a wide range of possibilities in terms of its management. This contributes to a better analysis of the damages that may affect them, to better identify the causes that originate them and to proceed with more precise and concrete intervention criteria, with the consequent economic repercussion.

On the one hand, LIDAR techniques allow us to model the buildings, their movements and deformations on a scale that we can quantify them until reaching accuracies of millimetres. Even get to compare the possible movements that a building or part of it in time has been able to undergo, by means of successive scans and controls on the same and obtaining quantitative data [1].

From another approach, the results of the obtaining of points clouds by the application of LIDAR techniques can also be applied in other GIS [2], [3] tools contributing more information about possible alterations, erosions and deteriorations in the elements and materials that make up the buildings [4], [5]. In addition, geographic information systems (GIS) also contribute to the cataloguing [6], analysis [7], [8] and presentation of results in a graphical and easily understandable format [9].

\section{LIDAR TECHNIQUES IN THE SURVEY AND MONITORING OF BUILT HERITAGE}

For the data acquisition, the graphic survey and its 3D modelling of the whole building, the use of the LIDAR terrestrial technology (Light Detection and Ranging) by means of a high precision laser scanner (TLS), focusing for this one study in the main facade and concretely in its doorway, conformed by great quantity and of sculptural and ornamental complex elements.

The laser scanner used is based on time-of-flight of a pulsed laser (Leica model ScanStation C10), which measures through a laser beam generating a point cloud of the scanned element with a maximum density of one point every $2 \mathrm{~mm}$ of distance, a complete field of view of $360^{\circ}$ in horizontal by $270^{\circ}$ in vertical, and a long reach (until $300 \mathrm{~m}$.). As for monitoring and data acquisition in the field has been carried out in 3 phases, and during the last three years (from 2014 to 2017) with the purpose of monitoring and controlling the evolution in erosion and deterioration of the sculptural elements.

The first phase of data acquisition, is performed on June 24th, 2014, on a cloudy day and with drizzle, with 2 stations point (Fig. 1).

Photographs are also obtained with the internal camera of the scanner to give the cloud of points of the real chromatism of the scanned element, being the appearance of the cloud of points obtained in its frontal view of the facade as can be seen in the following figure, Fig. 2.

The second day of field survey, is held on March 4th, 2016 on a sunny day. There are 6 stations with the aim of minimizing the shadow areas and the purpose of making this 3D data acquisition of the main front. The stations points are distributed as shown in Fig. 3. 
The last phase of field survey is done on March 29th, 2017 on a sunny day, performing 4 stations for data acquisition of the main front that will serve for comparison with the registration made on June 24, 2014 and study the erosion undergone during this time, Fig. 4.

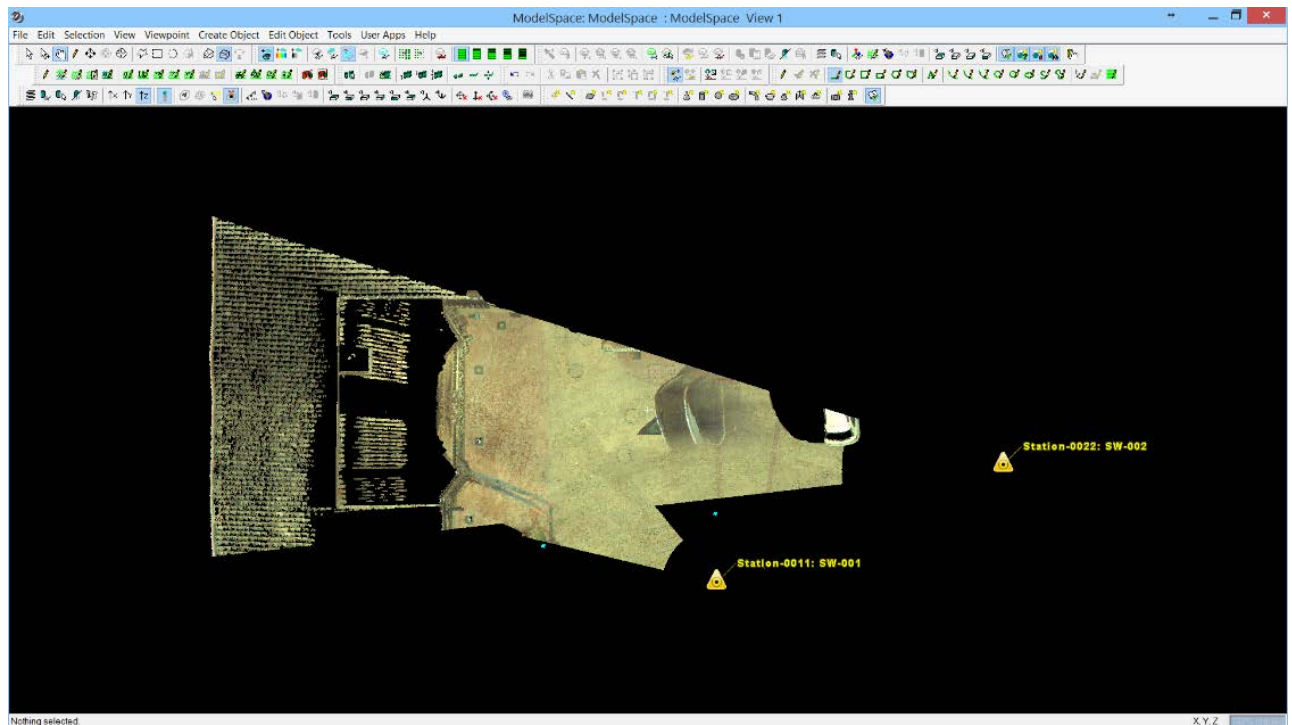

Figure 1: First phase of data acquisition (June 24th, 2014).

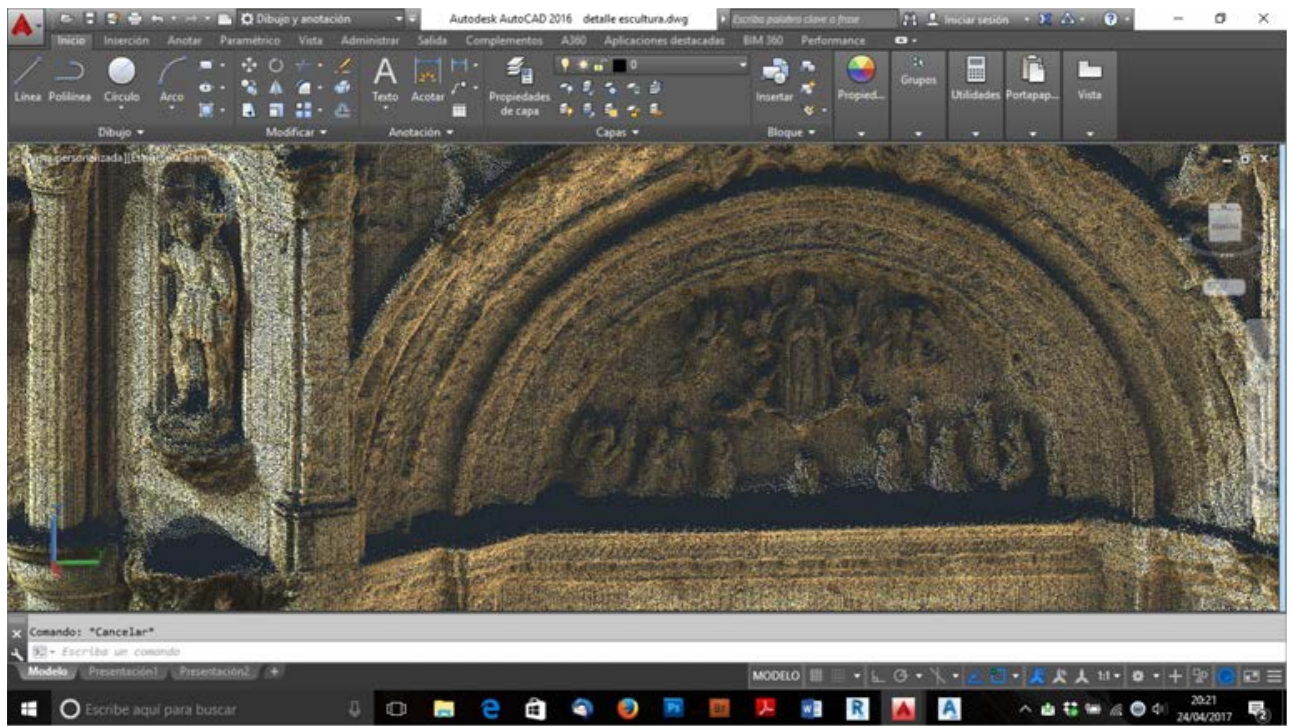

Figure 2: Detail of the real chromatism got with internal camera of the scanner. 


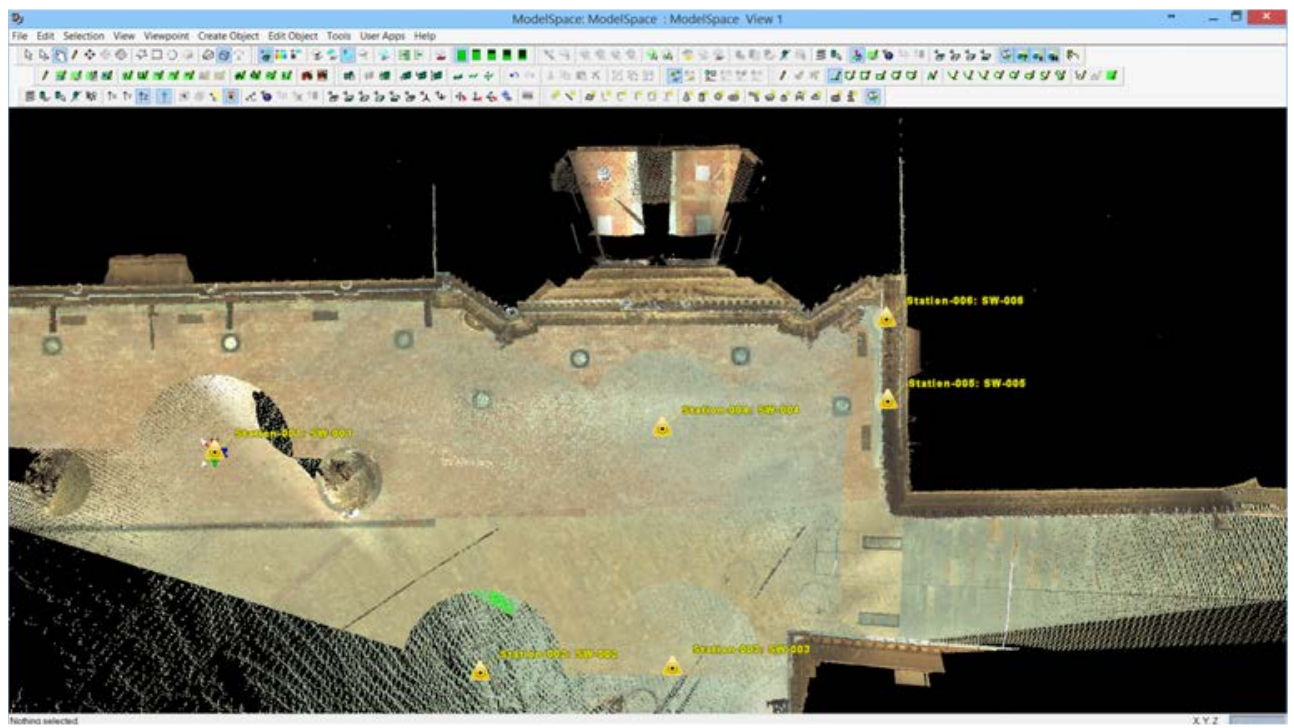

Figure 3: Second phase of data acquisition (March 4th, 2016).

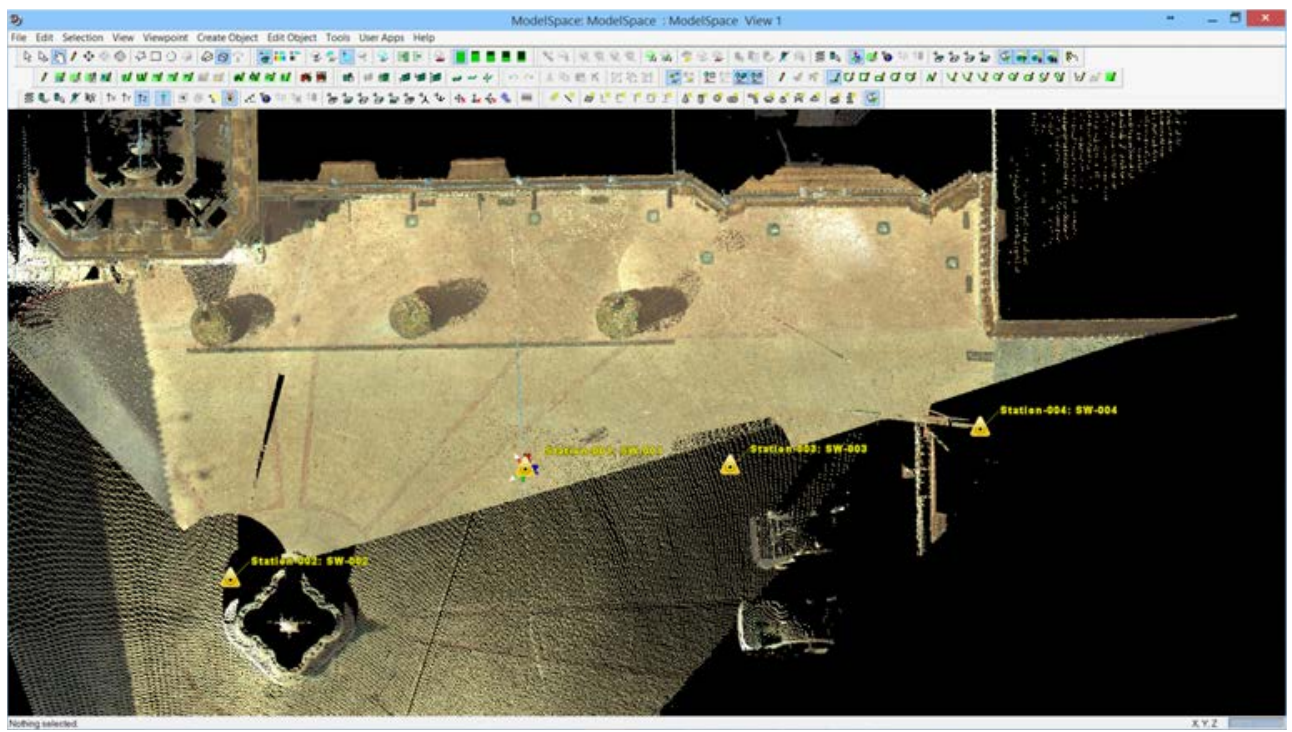

Figure 4: Third phase of data acquisition (March 29th, 2017).

\section{INTERPRETATION OF DATA}

For the registration and processing of the work we use the software Cyclone 9.0.1, with which we will unite the scan stations of each of the phases of the field survey and do the cleaning and filtering of the cloud of points.

For the first data acquisition in the field, the results of the register we obtain an error of $1 \mathrm{~mm}$, the results being satisfactory, Fig. 5 . 
The maximum error obtained in the registry between the different scan stations of the second survey phase is $5 \mathrm{~mm}$, acceptable error. Once the scan stations are united and after a process of cleaning and filtering the data, we export them in a *.pts file for conversion to the *.rcs format using the Autodesk RECAP 360 software.

The data obtained in the third phase of the field survey give us a maximum error of $1 \mathrm{~mm}$ between stations, Fig. 6 .

After the cleaning and filtering of the point clouds, we compared the results of the first phase of work with the third to analyse the behaviour of the sculptural elements of the main front during the almost 3 years of difference between scans. We use the software CloudCompare in its version 2.8.beta. First, we make a comparison between clouds limited to a maximum distance between points of $2 \mathrm{~cm}$ and once obtained the difference, we limit the results to the range between $3 \mathrm{~mm}$ and $10 \mathrm{~mm}$ difference between clouds of points. It must be taken into account that the scanner model used has an accuracy when measuring of +/- 2 mm, Fig. 7 .

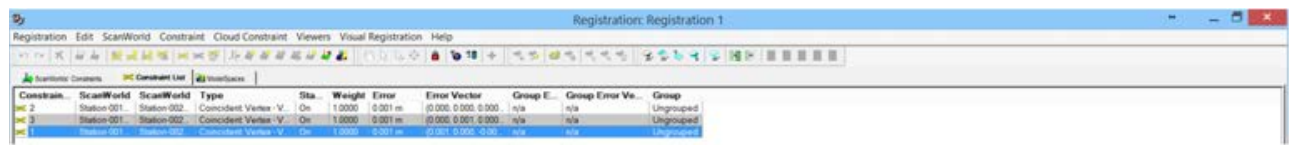

Figure 5: Results of the first data acquisition (June 24th, 2014).

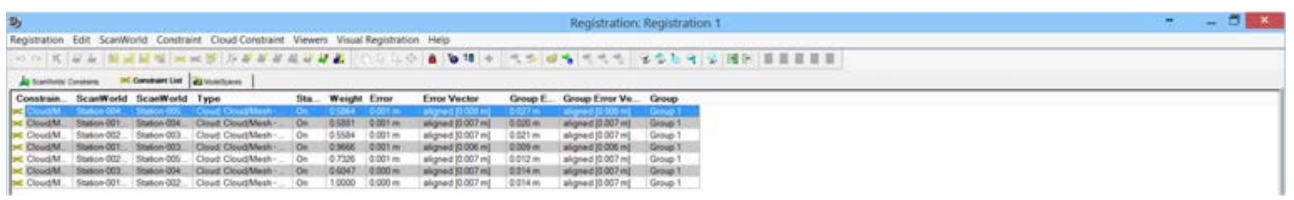

Figure 6: Results of the third data acquisition (March 29th, 2017).

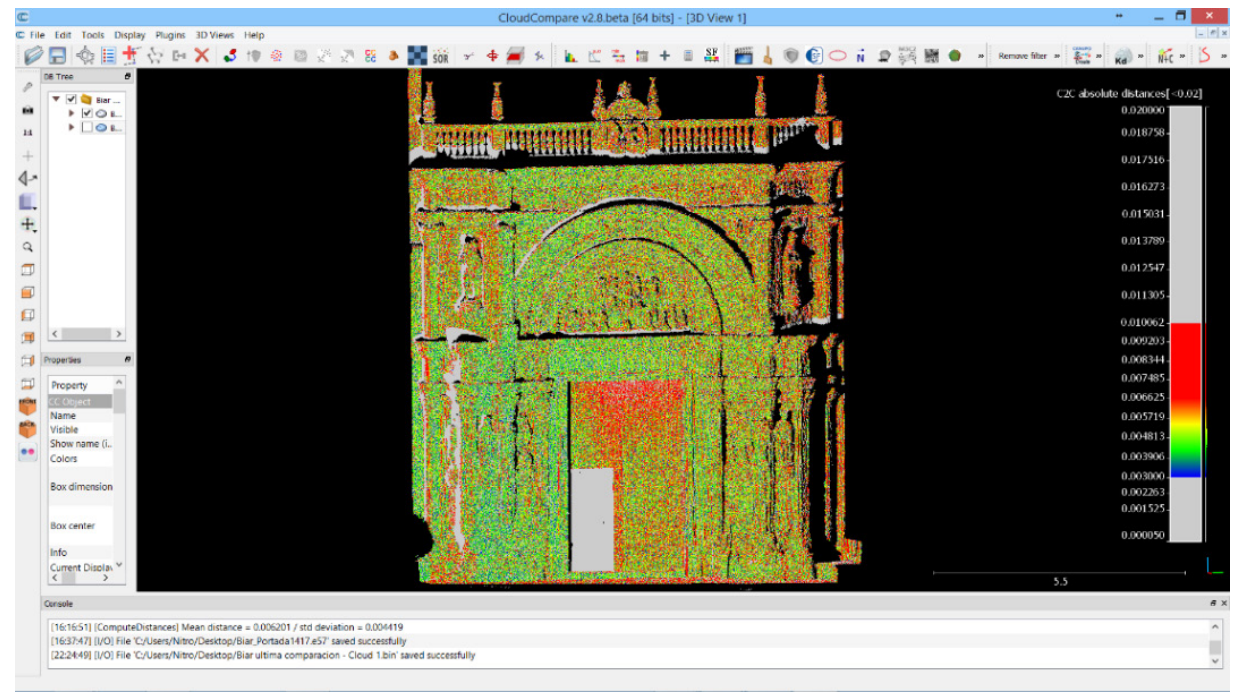

Figure 7: Using software CloudCompare to compare point clouds. 
We recalculate the difference between point clouds, starting from a deformation between $5 \mathrm{~mm}$ and $10 \mathrm{~mm}$, making a better filtering of the altered points between phase 1 and phase 3 to obtain the areas that have undergone more erosion, Fig. 8.

\section{DETAILED STUDY OF A MAIN FRONT AREA: AN EXAMPLE OF EROSION CONTROL OF MATERIALS}

After checking the possibilities offered by this methodology on the comparison of point clouds with the CloudCompare tool, we work and analyse in detail the areas susceptible to undergone some type of alteration by erosion. Focusing on the cornices and chapiters of the stone material that forms the main front, especially in those areas where rainwater drainage elements from the deck interact and are more exposed to the inclement weather (upper left), Fig. 9.

After the analysis by comparison of the data taken between 2014 and 2017, it is verified that there are indeed areas that have undergone losses in their volumetry, being able to verify in which range and in what value the element has been eroded. From these data could be obtained indicators on which areas have been most affected in the loss of the material in order to be able to make decisions on the priorities of intervention and the need for consolidation on the stone material, as well as the areas of detailed study of its components.

In the case in question and in particular of the upper exposed area of the chapitel of the second body of the main front, above the first cornice of the main façade, the losses of the material have been greater than $8 \mathrm{~cm}$ with respect to the first corresponding data (from 2014 to 2017). As well as those areas where there has been loss of the material of grouting of the ashlars that make up the outer wall of the main façade, Fig. 10.

\section{APPLICATION OF GEOGRAPHIC INFORMATION SYSTEMS (SIG) IN THE ANALYSIS AND CATALOGING OF MATERIALS}

Another very interesting and little exploited application for the benefit of heritage management is the use of GIS (Geographic Information Systems) as a tool for analysis and cataloguing of materials. In fact, for some years now it has become increasingly important in

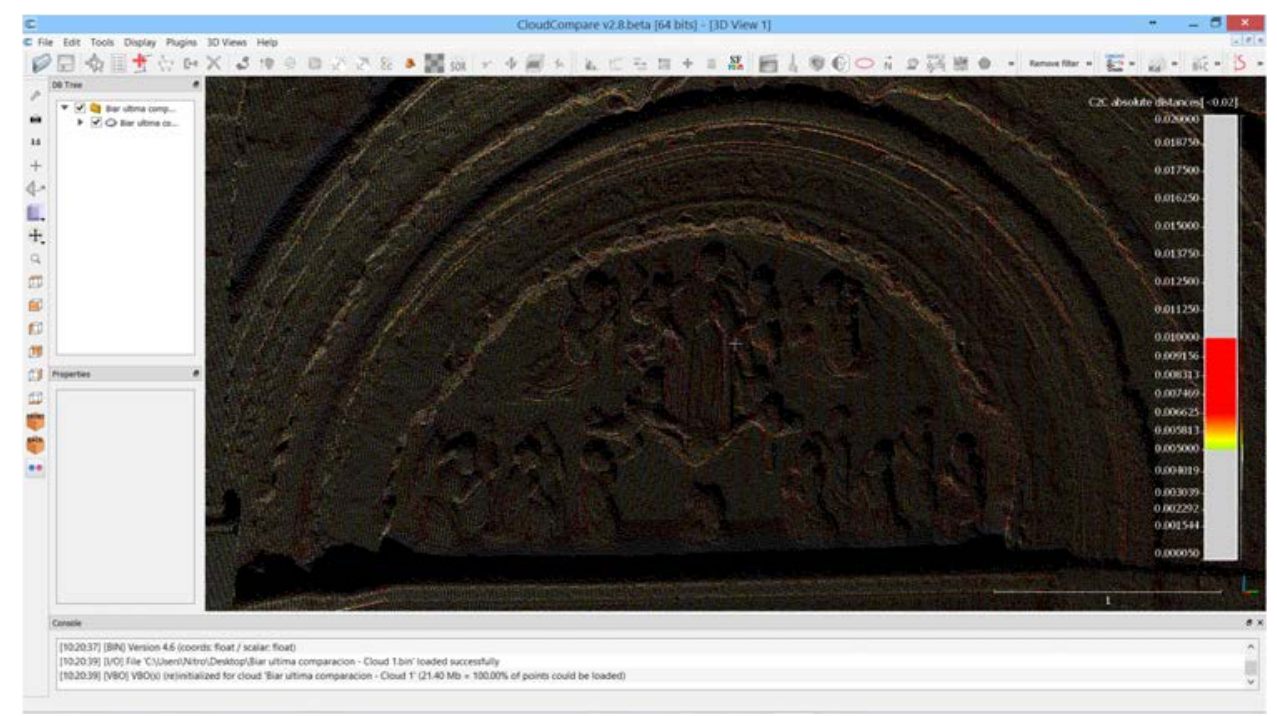

Figure 8: General results of the comparison of point clouds. 


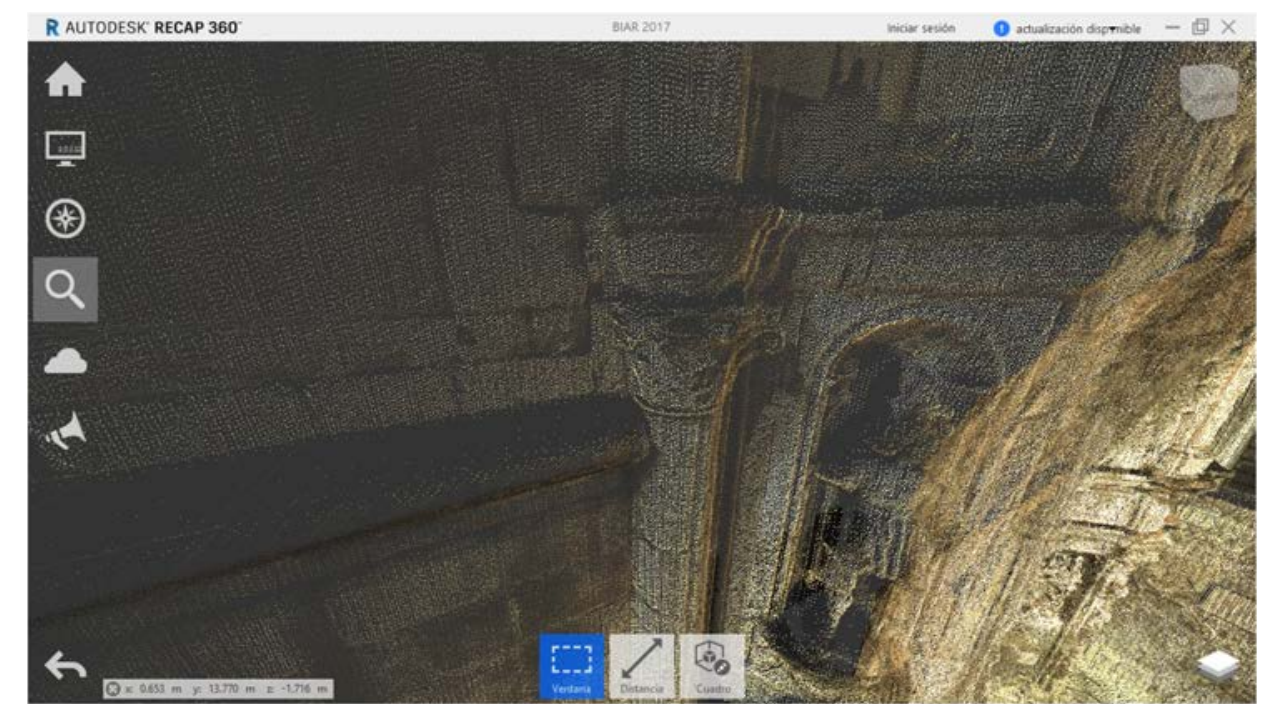

Figure 9: Detail of the column to study.

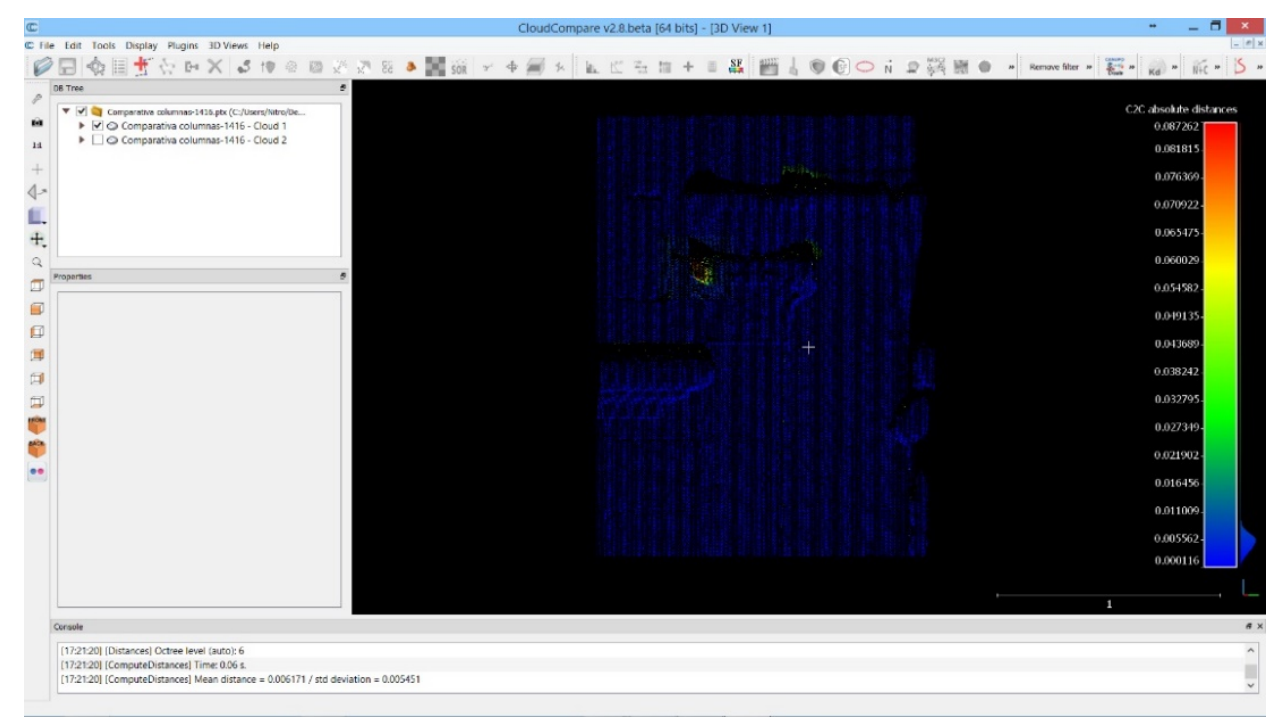

Figure 10: Comparison results point cloud and the erosion in the stone material.

the intervention of the heritage in the form of cataloguing of lesions that present the facade paintings, as well as in architectural archaeology or archaeology.

It has been used in this case for the study and mapping of lesions that appear in the materials as their cataloguing, as well as helped with raster images mapping the areas of the ashlars of the main façade that more erosion has suffered over time, Fig. 11. Using the tools of QGis for raster analysis and Autocad Map 3D for the cataloguing of elements and injuries, Fig. 12. 


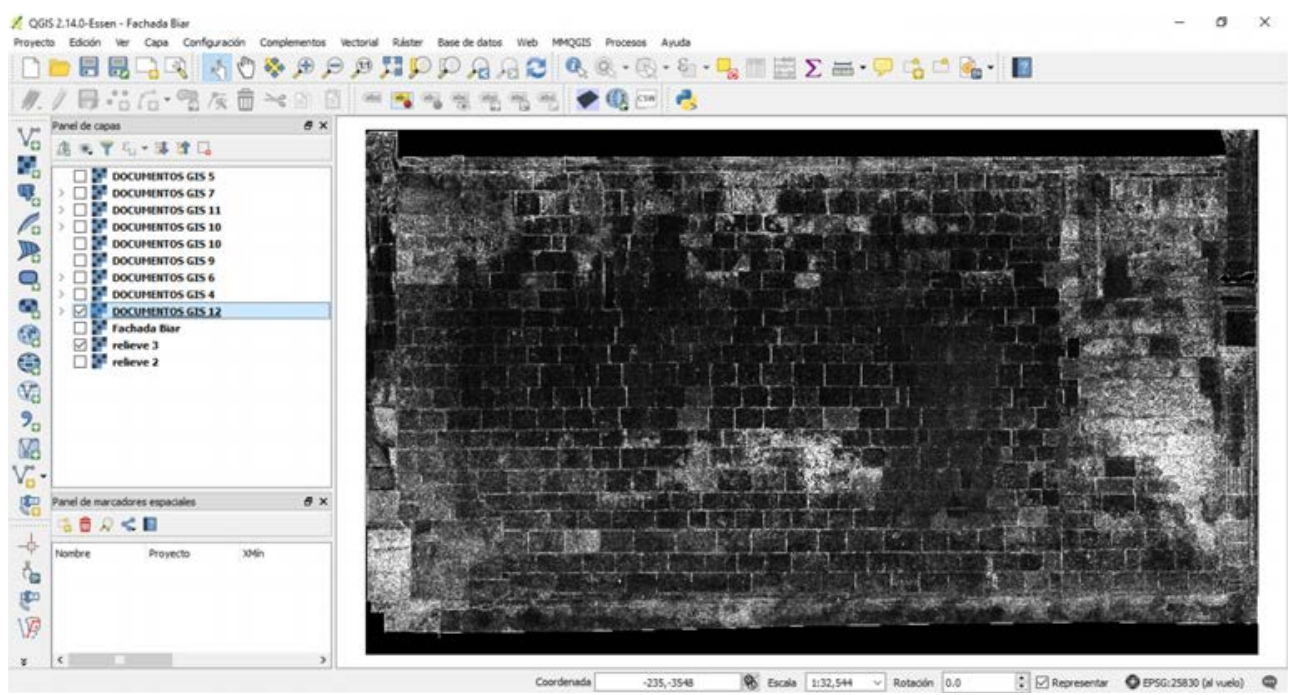

Figure 11: Mapping and visualization of lesions by QGis.

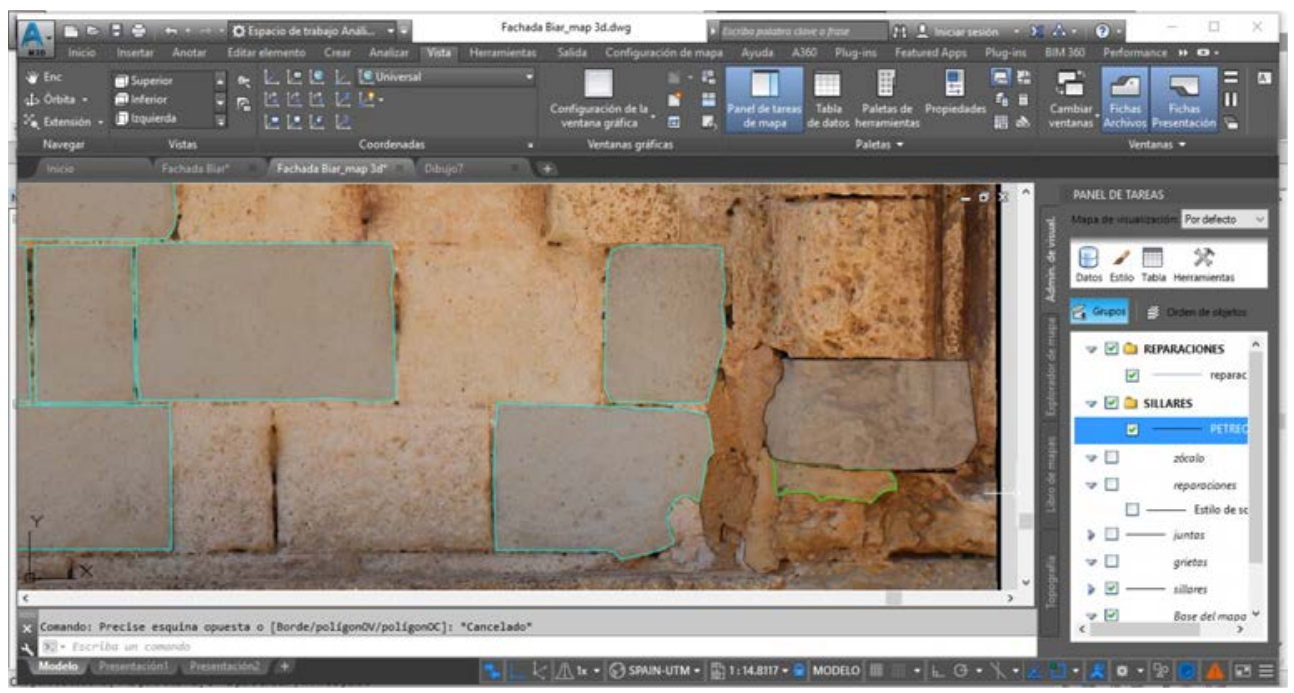

Figure 12: Cataloguing of injuries on the main front by Autocad Map 3D.

\section{CONCLUSIONS}

The new techniques and tools of common use in graphical surveys together with other applications and computer tools have contributed to the appearance of new applications in the field of the tests and non-destructive analysis, as they are the means of comparison of clouds of points along the time and the application of GIS for material analysis.

The results obtained from the comparison of the cloud of points, become quantitative objective indicators in the evaluation of the deformations and alterations undergone over time. For this reason, it is advisable to make any necessary intervention in the built heritage, 
as well as an indispensable basis in the cataloguing of the built heritage in which it is foreseen and required to be preserved and maintained.

As for the tools and software of GIS, they indicate that currently formats of free access can be found that can allow us to continue with this methodology of work and non-destructive analysis. At the same time, it makes it easier for us to implement such graphic information in the final technical documentation and that justify the technical interventions in architecture and restoration of the heritage.

\section{REFERENCES}

[1] Quattrini, R., Malinverni, E., Clini, P., Nespeca, R. \& Orlietti, E., From TLS to HBIM. High quality semantically-aware 3D modeling of complex architecture. The International Archives of Photogrammetry, Remote Sensing and Spatial Information Sciences, 40(5), p. 367, 2015.

[2] La Spina, V., La georreferenciación mediante SIG: Un instrumento de gestión del patrimonio arquitectónico, 2013.

[3] Seguí, A. E., Portalés, C., Cabrelles, M. \& Lerma, J. L., Los sistemas de información geográfica: Concepto, ventajas y posibilidades en el campo de la restauración. Loggia, Arquitectura \& Restauración, 24-25, pp. 122-131, 2012.

[4] López González, L., Aplicación De Herramientas GIS Para La Cartografía y Correlación De Datos De Ensayos no Destructivos En El Diagnóstico De Edificios Históricos, 2015.

[5] Reig, J. R., Los Sistemas De Información Geográfica y La Intervención En El Patrimonio Edificado: Ejemplo De Aplicación, 2013.

[6] La Spina, V., Mileto, C., López-Manzanares, F. V., \& Aliaga, P. E. C., La aplicación de un sistema de información geográfica (SIG) para la conservación del patrimonio arquitectónico: El estudio de los revestimientos continuos tradicionales del centro histórico de valencia. Arché, 6, pp. 323-332, 2011.

[7] Garzón, E., García, I., Ruiz-Conde, A. \& Sánchez-Soto, P., Aplicación de sistemas de información geográfica (SIG) en la prospección y caracterización de materias primas de interés en cerámica y vidrio. Boletín De La Sociedad Española De Cerámica y Vidrio, 48(1), pp. 39-44, 2009.

[8] Martín Pastor, A., Aguilar De Los Santos, R., Domínguez Ruiz, V., González Jiménez, J.M., Morón Orta, M. E., Torres Luque, E., “Aplicación de los sistemas de información geográfica (SIG) al estudio de edificios patrimoniales. Caso práctico: Actuación en el humilladero de San Onofre y su entorno. San Jerónimo, Sevilla”, en Proceedings Congreso Internacional Conjunto XVII Ingegraf - XV ADM, 1-3 Junio, Sevilla, Spain, 2005.

[9] Fornos, R. A., Construcción de la base gráfica para un sistema de información y gestión del patrimonio arquitectónico: Casa de hylas. Arqueología De La Arquitectura, 9, pp. 11-25, 2012. 